\title{
The Effect Of Determinant Factors In The Family On The Arrival Time Of Patients Stroke In Emergency Installation
}

\author{
M. Ikhwan Kosasih, Nugrahaeni Firdausi, Erwin Yektiningsih, Zauhani Kusnul* \\ STIKes Pamenang, Kediri, Indonesia \\ zauhani.kusnul@gmail.com
}

\begin{abstract}
Stroke is an emergency condition of cerebral blood vessels which until now has become an important health problem both in the world and Indonesia. Stroke is a non-communicable disease that has a large impact, can cause disability and even death. In the management of stroke the principle is that the sooner the better. In handling stroke known the term "golden period" or the golden period in the management of stroke. The speed with which a stroke sufferer gets the right treatment in a hospital has a big influence on the success of stroke management. This study was conducted to identify and analyze the influence of various factors in the family on the arrival time of stroke patients in the emergency department of the Kediri district hospital. The study was conducted during the months of mey-July 2019 and found stroke patients as many as 88 . In this study obtained data that among the factors of gender, age, education, and family work, only educational factors that have a significant relationship with the level of family knowledge. And from factors, age, education, level of knowledge, occupation, the first person to know the patient at the time of the attack, and decision makers in the family, the distance from the house to the hospital and the type of means of transportation to the hospital were found that family age, family work, people who knew first time the presence of a stroke and decision makers in the family have a significant relationship with the time interval between thr stroke attack with the arrival of patients in the emergency room. From this study it can be concluded that family factors play an important role in the time interval between a stroke and the arrival of a patient on IGD to get proper treatment.
\end{abstract}

Keywords: Family, Stroke, Time Interval, IGD 


\section{STRADA Jurnal Ilmiah Kesehatan}

DOI: $10.30994 /$ sjik.v9i1.

ISSN: 2252-3847 (print); 2614-350X (online)

Vol.9 No.1. May 2020. Page.44-53

\section{INTRODUCTION}

Stroke is an emergency condition of cerebral blood vessels which until now has become an important health problem both in the world and Indonesia. Epidemiological data show that stroke is the number 2 cause of death in the world after heart disease (1), whereas in Indonesia stroke is the number 1 cause of death with a national prevalence of $12.1 \% 0$ or 12 out of 1000 Indonesians have a tendency to have a stroke (2). The latest data from stroke shows that stroke is an important issue that deserves great attention.

Stroke is a non-communicable disease that has a large impact, can cause disability and even death. It is estimated that every 2 seconds there is 1 stroke in the world (1), dan setiap 6 detik terjadi kematian akibat stroke (3). In addition to causing high mortality rates, strokes also cause disability and death in sufferers, strokes also have a wider impact to the economic and social sectors. The economic impact arises because a stroke sufferer requires a relatively long treatment time so this causes a stroke sufferer unable to work productively, besides that stroke treatment requires high costs.

The economic impact will get worse if stroke sufferers experience permanent disability. The social impact is very potential to occur in stroke sufferers because the disability experienced will reduce various functional abilities of a person and cause a person to no longer be able to perform various roles as before illness (4).

The severity of disability caused by a stroke is influenced by many internal and external factors. Internally it is affected by which areas of the brain are affected and the severity of the disturbance that occurs. Externally influenced by various factors related to the management of stroke including the speed and accuracy of its management (5).

In the management of a stroke the principle is that the sooner the right treatment gets the better the results. In handling stroke known the term "golden period" or the golden period in the management of stroke. Some studies say that the handling of ischemic strokes within 3-5 hours after an attack gives effective results, and the effectiveness of the intervention / treatment of stroke will decrease along with the longer handling of the onset of stroke (6). The delay of most acute ischemic stroke patients coming to the health service (emergency department) has a negative impact on the success of stroke management (7). The speed of a stroke sufferer getting the right treatment in hospitals has a big influence on the success of stroke management. Where this can be increased by minimizing the time span of coming to the emergency department of the onset of a stroke (8).

This research was conducted to identify and analyze the influence of various factors in the family such as; gender, age, education, and occupation, the first person to know of a stroke, the decision maker in handling stroke patients, the distance of the house to the hospital, and the means of transportation to the hospital against the time interval between a stroke and the arrival of a stroke patient at the district hospital emergency department Kediri.

\section{METHODS}

This study was an observational analytic study with a cross sectional approach in the Emergency Department of Kediri District Hospital in May to July 2019. The research subjects were family members (husband, wife, children, grandchildren / siblings) of stroke patients who knew and were directly involved in carrying patient to the hospital. The dependent variable of this study is the time interval between a stroke and the arrival of a patient in the hospital emergency room, with the variable between the level of family knowledge about stroke and the independent variables covering general data of the patient and the patient's family such as gender, age, education, and occupation, and special data 


\section{STRADA Jurnal Ilmiah Kesehatan}

DOI: $10.30994 /$ sjik.v9i1.

ISSN: 2252-3847 (print); 2614-350X (online)

Vol.9 No.1. May 2020. Page.44-53

including ; the first person to know about a stroke, the decision maker in handling stroke patients, the distance from the house to the hospital, and the means of transportation to the hospital.

Data is collected by structured interview techniques using a questionnaire sheet guide. The collected data is then processed, tabulated and univariate analysis is carried out to get an overview of general data. Categorizing the respondent's knowledge level uses the results of measurements of the mean and standard deviation of the respondents' score answers. Where made three (3) categories, namely good, enough, and less. The interval / time span between attacks to the arrival of patients in the emergency room is categorized into $<3$ hours, 3- $<6$ hours and $>6$ hours. Furthermore, to determine the relationship between variables, correlation analysis was performed using SPSS 18 software.

\section{RESULTS}

\section{General Characteristics}

During the time span of the study (May-July 2019) 88 stroke patients were found who came to the emergency room at Pare Regional Hospital. Out of a total of 88 stroke sufferers, more than half are male, with a majority of over 56 years of age, with the majority of elementary school education levels, and the majority are not working or working as entrepreneurs. While the family members of patients found that the majority of female sex, most in the age range of 26-45 years, with the highest education level of high school, and the most types of work are self-employed (table 1).

Table 1. General characteristics of stroke patients and families in Kediri District Hospital in May-July 2019

\begin{tabular}{|c|c|c|c|c|c|}
\hline \multicolumn{2}{|c|}{ Characteristics } & \multicolumn{2}{|c|}{ Patient } & \multicolumn{2}{|c|}{ Patient's Family } \\
\hline & & $\mathrm{N}$ & $\%$ & $\mathrm{~N}$ & $\%$ \\
\hline \multirow[t]{2}{*}{ Gender } & Male & 49 & 55,7 & 39 & 44,3 \\
\hline & Female & 39 & 44,3 & 49 & 55,7 \\
\hline \multirow[t]{5}{*}{ Age } & $<25$ year & - & - & 5 & 5,7 \\
\hline & 26-35 year & - & - & 31 & 35,2 \\
\hline & $36-45$ year & 7 & 8 & 34 & 38,6 \\
\hline & 46-55 year & 14 & 15,9 & 12 & 13,6 \\
\hline & $>56$ year & 67 & 76,1 & 6 & 6,8 \\
\hline \multirow[t]{5}{*}{ Education } & No school & 10 & 11,4 & 2 & 2,3 \\
\hline & Elementary school & 37 & 42 & 13 & 14,8 \\
\hline & Yunior high school & 18 & 20,5 & 26 & 29,5 \\
\hline & Senior high school & 20 & 22,7 & 41 & 46.6 \\
\hline & University & 3 & 3,4 & 6 & 6,8 \\
\hline \multirow[t]{6}{*}{ Occupation } & Non job & 27 & 30,7 & 23 & 26,1 \\
\hline & employee & 9 & 10,2 & 21 & 23,9 \\
\hline & enterpreneur & 27 & 30,7 & 26 & 29,5 \\
\hline & farmer & 20 & 22,7 & 11 & 12,5 \\
\hline & State employee & 2 & 3,4 & 6 & 6,8 \\
\hline & retirement & 3 & 2,3 & 1 & 1,1 \\
\hline
\end{tabular}

The level of knowledge of family members about stroke

The level of knowledge in the study measured in this study includes knowledge of the meaning of stroke, causes of stroke, symptoms of stroke, what to do with family members who have had a stroke, and the impact / complications of stroke. In this study the level of 


\section{STRADA Jurnal Ilmiah Kesehatan}

DOI: $10.30994 /$ sjik.v9i1.

ISSN: 2252-3847 (print); 2614-350X (online)

Vol.9 No.1. May 2020. Page.44-53

knowledge of respondents was grouped into good, enough and less and obtained the distribution of the level of knowledge of the families of stroke patients in the good category as much as $51.1 \%$.

Table 2; Frequency distribution of the level of patient's family knowledge about stroke

\begin{tabular}{ccc}
\hline Knowledge level & Amount & Percent $(\%)$ \\
\hline High & 45 & 51,1 \\
Moderate & 17 & 19,3 \\
Low & 26 & 29,5 \\
\hline
\end{tabular}

Furthermore, to find out what factors influence the level of knowledge of the patient's family, cross tabulation and correlation analysis between general characteristics such as age, education and occupation with the level of knowledge (table 3). Furthermore, gender, age, education, and occupation variables were tested for correlation with the level of knowledge using the SPSS 18 Spearmen correlation test and found that only family education had a significant correlation with the level of knowledge with a significance value of 0.03 .

Table 3; Cross tabulation of general characteristics of stroke patient families with level of knowledge

\begin{tabular}{|c|c|c|c|c|c|}
\hline \multirow{2}{*}{\multicolumn{2}{|c|}{ General Characteristics }} & \multicolumn{3}{|c|}{ Level of Knowledge $(n=88)$} & \multirow{2}{*}{$\begin{array}{c}\text { Signifikancy } \\
\text { value }\end{array}$} \\
\hline & & High & Moderate & Low & \\
\hline \multirow[t]{2}{*}{ Gender } & Male & 18 & 5 & 16 & \multirow[t]{2}{*}{0,151} \\
\hline & Female & 27 & 12 & 10 & \\
\hline \multirow[t]{5}{*}{ Age } & $<25$ year & 3 & 1 & 1 & \multirow[t]{5}{*}{0,234} \\
\hline & 26-35 year & 10 & 5 & 3 & \\
\hline & $36-45$ year & 7 & 4 & 2 & \\
\hline & 46-55 year & 16 & 4 & 14 & \\
\hline & $>56$ year & 9 & 3 & 6 & \\
\hline \multirow[t]{5}{*}{ Education } & No school & 1 & 0 & 1 & \multirow[t]{5}{*}{0,03} \\
\hline & Elementary school & 5 & 2 & 6 & \\
\hline & Yunior high school & 10 & 7 & 9 & \\
\hline & Senior high school & 25 & 7 & 9 & \\
\hline & University & 4 & 1 & 1 & \\
\hline \multirow[t]{6}{*}{ Occupation } & Non job & 15 & 5 & 3 & \multirow[t]{6}{*}{0,325} \\
\hline & employee & 11 & 3 & 7 & \\
\hline & enterpreneur & 12 & 6 & 8 & \\
\hline & farmer & 2 & 2 & 7 & \\
\hline & State employee & 4 & 1 & 1 & \\
\hline & retirement & 1 & 0 & 0 & \\
\hline
\end{tabular}

The time interval between the attack and the arrival of stroke sufferers in the emergency room 


\section{STRADA Jurnal Ilmiah Kesehatan}

DOI: $10.30994 /$ sjik.v9i1.

ISSN: 2252-3847 (print); 2614-350X (online)

Vol.9 No.1. May 2020. Page.44-53

The interval / time span between attacks to the arrival of patients in the emergency room is categorized as $<3$ hours, 3- $<6$ hours and $>6$ hours, and as many as $51.5 \%$ of stroke patients come to the emergency room before 3 hours after a stroke. The rest come between 3-6 hours after a stroke and a small portion 6 hours after a stroke.

Table 4; The time interval between the attack and the arrival of stroke sufferers at the Kediri District General Hospital emergency room in May-July 2019

\begin{tabular}{ccc}
\hline Interval of time & amount & Percent $(\%)$ \\
\hline$<3$ hour & 45 & 51,1 \\
$3-6$ hour & 24 & 27,3 \\
$>6$ hour & 19 & 21,6 \\
\hline
\end{tabular}

To find out more about what factors are significantly related to the time interval between the attack and the arrival of stroke patients in the emergency room, cross tabulation and correlation analysis between the variables of age, education, occupation, the first person to know the patient at the time of the attack, decision makers in the family, home distance with hospitals and types of transportation facilities to hospitals with time intervals between attacks and the arrival of stroke patients in the emergency room.

Among the factors of gender, age, education, occupation, the first person to know a stroke, decision makers in handling stroke patients, the distance to the hospital, transportation facilities to the hospital, and family knowledge, which has a significant correlation with the time interval between stroke with the arrival of patients in the emergency room is family age, family work, people who know the first time there was a stroke and decision makers in the family have a significant relationship with a significance value of 0.001 , $0.034,0.032$ and 0.008 , respectively. While gender, education, distance of the house to the hospital, means of transportation to the hospital and the level of family knowledge do not have a significant correlation with the time interval between a stroke and the arrival of patients in the emergency room.

Table 5; Cross tabulation

Characteristics of Respondents the time interval between the Significance
attack and the arrival of the value stroke sufferer in the emergency room, in hours $(n=88)$

\begin{tabular}{|c|c|c|c|c|c|}
\hline & & $<3$ hour & 3-6 Hour & $>6$ hour & \\
\hline \multirow[t]{2}{*}{ Gender } & Male & 22 & 9 & 8 & \multirow[t]{2}{*}{0,46} \\
\hline & female & 23 & 15 & 11 & \\
\hline \multirow[t]{5}{*}{ Age } & $<25$ year & 1 & 3 & 1 & \multirow[t]{5}{*}{0,001} \\
\hline & 26-35 year & 6 & 5 & 5 & \\
\hline & 36-45 year & 5 & 5 & 5 & \\
\hline & 46-55 year & 19 & 8 & 7 & \\
\hline & $>56$ year & 27 & 11 & 8 & \\
\hline \multirow[t]{3}{*}{ Education } & No school & 2 & 0 & 0 & \multirow[t]{3}{*}{0,908} \\
\hline & $\begin{array}{l}\text { Elementary } \\
\text { school }\end{array}$ & 7 & 4 & 2 & \\
\hline & $\begin{array}{l}\text { Yunior high } \\
\text { school }\end{array}$ & 13 & 6 & 7 & \\
\hline
\end{tabular}


STRADA Jurnal Ilmiah Kesehatan

DOI: $10.30994 /$ sjik.v9i1.

ISSN: 2252-3847 (print); 2614-350X (online)

Vol.9 No.1. May 2020. Page.44-53

\begin{tabular}{|c|c|c|c|c|c|}
\hline & $\begin{array}{l}\text { Senior high } \\
\text { school }\end{array}$ & 18 & 13 & 10 & \\
\hline & University & 5 & 1 & 0 & \\
\hline \multirow[t]{6}{*}{ Occupation } & Non job & 1 & 0 & 0 & \multirow[t]{6}{*}{0,034} \\
\hline & employee & 5 & 10 & 6 & \\
\hline & enterpreneur & 15 & 4 & 7 & \\
\hline & farmer & 9 & 2 & 0 & \\
\hline & State employee & 5 & 1 & 0 & \\
\hline & retirement & 1 & 0 & 0 & \\
\hline \multirow{2}{*}{$\begin{array}{l}\text { The first person } \\
\text { to know about a } \\
\text { stroke }\end{array}$} & Family & 45 & 21 & 17 & \multirow[t]{2}{*}{0,032} \\
\hline & $\begin{array}{l}\text { Other people, } \\
\text { neighbour, ect }\end{array}$ & 0 & 3 & 2 & \\
\hline \multirow{5}{*}{$\begin{array}{l}\text { Decision maker } \\
\text { in handling } \\
\text { stroke patients }\end{array}$} & Patient himself & 1 & 0 & 0 & \multirow[t]{5}{*}{0,008} \\
\hline & couple & 23 & 9 & 2 & \\
\hline & parent & 0 & 1 & 1 & \\
\hline & child & 17 & 10 & 14 & \\
\hline & Other family & 4 & 4 & 2 & \\
\hline \multirow{4}{*}{$\begin{array}{l}\text { Distance Home } \\
\text { to Hospital }\end{array}$} & $1-5 \mathrm{~km}$ & 3 & 2 & 0 & \multirow[t]{4}{*}{0,776} \\
\hline & $6-10 \mathrm{~km}$ & 17 & 5 & 10 & \\
\hline & $11-15 \mathrm{~km}$ & 12 & 7 & 7 & \\
\hline & $>15 \mathrm{~km}$ & 13 & 10 & 2 & \\
\hline \multirow{2}{*}{$\begin{array}{l}\text { Means of } \\
\text { transportation } \\
\text { to the hospital }\end{array}$} & Personal car & 40 & 20 & 16 & \multirow[t]{2}{*}{0,57} \\
\hline & $\begin{array}{l}\text { Public } \\
\text { transportation }\end{array}$ & 5 & 4 & 3 & \\
\hline \multirow{3}{*}{$\begin{array}{l}\text { Family } \\
\text { Knowledge }\end{array}$} & High & 21 & 14 & 10 & \multirow[t]{3}{*}{0,319} \\
\hline & Moderate & 8 & 4 & 5 & \\
\hline & Low & 16 & 6 & 4 & \\
\hline
\end{tabular}

\section{DISCUSSION}

\section{General Characteristics}

In this study, it was found that stroke patients were more male (55.7\%). The results of this study are in line with data obtained by Coal, 2015 which found that male stroke sufferers were more than female (9). In other publications also mentioned that sex is one of the important risk factors for stroke (10). This can be caused by the behavior that is generally done by many men but rarely done by women, one of which is smoking. Smoking is still one of the important risk factors for stroke (11).

From the age side, in this study it was found that the majority of stroke sufferers were aged over 65 years $(76.1 \%)$. This is also in line with some previous studies which mention that age is one of the risk factors for stroke, and data to date indicate that age is one of the risk factors for stroke $(9,11)$. Why is age a risk factor for stroke? This can be related to various degeneration processes that occur in the human body as we get older. The incidence of stroke is related to the condition of blood vessels, where as we get older, blood vessels also experience the process of degeneration to be susceptible to experience problems related to the occurrence of various diseases such as stroke (12). It is also related to various diseases 


\section{STRADA Jurnal Ilmiah Kesehatan}

DOI: $10.30994 /$ sjik.v9i1.

which are risk factors for stroke such as hypertension and diabetes mellitus which also increases with age (9).

From the education level perspective, we found that stroke patients came from uneducated to tertiary education groups, with stroke sufferers from groups with tertiary education at the lowest percentage. $(3,4 \%)$ and from the group with primary school education occupies the largest percentage $(42 \%)$. This can be related to the increased ability of a person to access various information about various disease prevention efforts and healthy living behavior along with the increasing level of education. Along with improving one's education will potentially get and understand various health messages for later applied. Although in many cases the reality is also found that increasing the level of education does not always significantly change the knowledge and behavior of healthy living.

From the type of work it was found that there were no striking differences between groups. The unemployed and entrepreneurial groups each accounted for $30.7 \%$ and the remainder were spread out from other occupational groups. This data does not provide a clear distinction between different types of work and the incidence of stroke.

Data on the family of patients who accompany the majority of women in hospitals, according to the role and function of women in the family where women are the most active role in determining family health, especially in caring for sick family members (13). In terms of the age of the majority of families who accompany stroke patients under 45 years of age, this is because in caring for sick family members and being treated at the hospital it takes a person who is still physically strong and someone under the age of 45 years is still very possible to make income and care well. The majority of family members who accompany stroke sufferers at the hospital. In terms of the level of education the majority of family members have a high school education, this is possible with the consideration that while in the hospital needed a family member who is able to interact with the health team, is also able to understand various procedures and provisions that apply in hospitals. Someone with a high school education is very possible to be able to understand this well. Furthermore, in terms of the type of work, the majority do not work / work as entrepreneurs, this is possible because to take care of sick family members in hospitals requires a relatively long time so that family members who do not work / work as entrepreneurs are the most possible for it compared to those who work as civil servants or employees who are bound by working hours.

\section{The level of knowledge of family members about stroke}

The level of family knowledge about stroke in this study found more than half were in the good category $(51.1 \%)$, but those included in the less category were still relatively large (29.5\%) (table 4). Gender, age, education, and occupation were tested for correlation with level of knowledge using the SPSS 18 Spearmen correlation test and found that only family education had a significant correlation with level of knowledge with a significance value of 0.03 . This result is relevant to the findings of previous studies which say that education level is an important determinant factor for knowledge level (14). This is possible because with a higher level of education someone will have the opportunity to understand information better. At present various health information can be accessed through various media so that the general public can also get information related to health issues, depending on the ability of each individual to access and understand it.

The time interval between the attack and the arrival of stroke sufferers in the emergency room 


\section{STRADA Jurnal Ilmiah Kesehatan}

DOI: $10.30994 /$ sjik.v9i1.

ISSN: 2252-3847 (print); 2614-350X (online)

Vol.9 No.1. May 2020. Page.44-53

The distribution of the interval / time span between attacks until the arrival of patients in the emergency room before 3 hours after a stroke occupies the largest percentage of $51.1 \%$. This result is almost equivalent to the results of Rahmina's research (2017) which found that stroke patients who came before the golden hour at Ulin Banjarmasin Hospital were $60 \%(15)$. But this result is higher than the results of Prasetya's research (2017) in 5 hospitals in DKI Jakarta which found that those who came to the hospital <3 hours amounted to $24.5 \%$ (16). The results vary between regions can be due to the variety of determinants that exist in each region, both from individual factors, socio-economic, demographic, knowledge and so forth. This also shows that the urban community, in this case in the DKI Jakarta area, does not always have a faster response to stroke patients compared to a rather peripheral area. What factors that influence still need further study, this can also be influenced by the volume of work in urban areas that are higher than from the area so that the measured city community has a slower response in bringing stroke patients to the hospital.

Factors that have a significant relationship with the interval / time span between attacks to the arrival of patients in the emergency room are family age. With the majority family age under 45 years. The age factor influences decision making because the age factor is related to mental abilities and adjusting to new situations, analogical reasoning and creative thinking (17). This theory supports the fact that the older the family the better the response to bring stroke patients to the hospital.

Family work also has a significant relationship with the interval / time span between attacks to the arrival of patients in the emergency room. The type of work can affect whether or not a family response quickly in bringing a stroke sufferer to hospital. This is due to several types of institutional work such as civil servants and private employees who require working time ties (days and hours) so that this can affect the time to bring sick family members. An employee who will leave the office during office hours must at least carry out licensing procedures with his supervisor. This is evident in the data from this study (table 5) that most stroke patients arrive at the hospital before the first 3 hours of stroke, the type of work their families are self-employed. This is possible because the work of the entrepreneur has the discretion to manage his own time, so that the family can bring in stroke patients as soon as an attack is found.

One of the factors that affects whether or not a stroke sufferer is brought to the hospital is who is the first person to notice a stroke. Of the 88 stroke patients in this study, as many as 45 people arrived at the hospital before 3 hours after a stroke came from a group where the first person to notice a stroke was family (table 5). This shows that the existence of the family plays a very important role. The family is the closest person who has an important role in providing daily care, recognizing health problems and making decisions about actions to be taken to overcome health problems experienced by one family member (18). One thing that also has a significant effect on the interval / time span between an attack and the arrival of patients in the emergency room is the decision maker in the family. The decision making process is a unique, and complex process involving interactions between various related factors. Various factors that influence family decisions including individual internal factors such as age, gender, education, knowledge, and beliefs, in addition to socio-economic factors also dynamics that occur in a family are also involved in it. In this study, from the group of patients who arrived at the hospital before 3 hours the majority of decision makers were couples (husband / wife of the patient) and then followed by children as decision makers (table 5). This shows that in the majority of Indonesian family structure the nuclear family has a very important position. The nuclear family has the main 


\section{STRADA Jurnal Ilmiah Kesehatan}

DOI: $10.30994 /$ sjik.v9i1.

ISSN: 2252-3847 (print); 2614-350X (online)

Vol.9 No.1. May 2020. Page.44-53

role in deciding an action for a sick family member (19). The success of the family deciding on the right action is the success of all components of the family involved, if the family is able to decide on an appropriate action then it will have a positive impact on the health aspects of family members and also on the family's future in general in the long term. This shows that the family is an important part to get attention in various health promotion programs. Families who are able to recognize health problems, are able to take the right decisions, are able to take appropriate actions and are able to access various health facilities will strengthen the Indonesian people to achieve improved health status and a better life.

\section{CONCLUSION}

1. The level of family education has a significant correlation with the level of knowledge about stroke.

2. Family age, family work, people who know the first time there is a stroke and decision makers in the family have a significant relationship with the time interval between a stroke with the arrival of patients in the emergency room.

\section{ACKNOWLEDGMENTS}

Thank you to the DRPM Ministry of Research and Technology and Higher Education who have supported funding for the implementation of this research through a Beginner Lecturer Research grant

\section{REFERENCES}

1. Direktorat Jendral Pencegahan dan Pengendalian Penyakit KR. Kebijakan dan strategi pencegahan dan pengendalian stroke di Indonesia. 2018.

2. Balitbangkes Kemenkes RI. Riset Kesehatan Dasar 2013. 2014.

3. Kumar AJ, Nambiar V V. Stroke Progression. Universal Journal of Medical Science. Science (80- ). 2015;3(3):60-4.

4. Wang S, Shen B, Wu M, Chen C, Wang J. Effects of socioeconomic status on risk of ischemic stroke: A case-control study in the Guangzhou population. BMC Public Health. 2019;19(1):1-7.

5. Sadeghi-Hokmabadi E, Farhoudi M, Taheraghdam A, Rikhtegar R, Ghafouri RR, Asadi R, et al. Prehospital notification can effectively reduce in-hospital delay for thrombolysis in acute stroke. Future Neurol. 2018;13(1):5-11.

6. Lu Y, Sun T, Ding Y, Diao S, Li T, Cai X, et al. Translational Perioperative and Pain Medicine Pre- and In-Hospital Management of Stroke. 2019;6(3).

7. Fekadu G, Wakassa H, Tekle F. Stroke Event Factors among Adult Patients Admitted to Stroke Unit of Jimma University Medical Center: Prospective Observational Study. Stroke Res Treat. 2019;2019.

8. Mathur S, Walter S, Grunwald IQ, Helwig SA, Lesmeister M, Fassbender K. Improving Prehospital Stroke Services in Rural and Underserved Settings With Mobile Stroke Units. Front Neurol. 2019;10(March):1-11.

9. Batubara S, Tat F. Hubungan Antara Penanganan Awal Dan Luasnya Kerusakan Neurologis Pasien Stroke Di RSUD Kupang. Soedirman J Nurs. 2015;10(3):143-57.

10. A. Boehme, C. Esenwa ME. Stroke: Risk factors and prevention. J Pak Med Assoc [Internet]. 2018;60(5):412. Available from: http://jpma.org.pk/PdfDownload/2062.pdf\%5Cnhttp://ovidsp.ovid.com/ovidweb.cgi?T $=\mathrm{JS} \& \mathrm{PAGE}=$ reference $\& \mathrm{D}=\mathrm{emed} 9 \& \mathrm{NEWS}=\mathrm{N} \& \mathrm{AN}=2010239168$ 


\section{STRADA Jurnal Ilmiah Kesehatan}

DOI: $10.30994 /$ sjik.v9i1.

ISSN: 2252-3847 (print); 2614-350X (online)

Vol.9 No.1. May 2020. Page.44-53

11. Abduljabbar M, Alqahtani H, Alqahtani A, Alharbi A, Aldhehyan T, Alsharif A. The role of known risk factors and the pre-stroke lifestyle among elderly Saudi stroke patients in Riyadh City. Int J Med Dev Ctries. 2019;3(January):428-34.

12. Trinh M, Kalloniatis M, Nivison-smith L. Vascular Changes in Intermediate AgeRelated Macular Degeneration Quantified Using Optical Coherence Tomography Angiography. 2019;8(4).

13. Zahrok S, Suarmini NW. Peran Perempuan Dalam Keluarga. IPTEK J Proc Ser. 2018;0(5):61.

14. Diaz-Quijano FA, Martínez-Vega RA, Rodriguez-Morales AJ, Rojas-Calero RA, Luna-González ML, Díaz-Quijano RG. Association between the level of education and knowledge, attitudes and practices regarding dengue in the Caribbean region of Colombia. BMC Public Health. 2018;18(1):1-10.

15. Rahmina Y, Wahid A, Agustina R. Tingkat Pendidikan Keluarga Terhadap Golden Hour Pasien Stroke Di Rsud Ulin Banjarmasin. Dunia Keperawatan. 2017;5(1):68.

16. Prasetyo E. Faktor-faktor yang Mempengaruhi Keterlambatan Pasien Stroke Akut Datang ke Lima Rumah Sakit Pemerintah di DKI Jakarta. Maj Kesehat Pharmamedika. 2018;9(1):040.

17. Osmani J. The Impact of Age on the Perception of Cognitive Abilities and DecisionMaking Skills. Eur J Soc Sci Educ Res. 2016;8(1):114.

18. Murdiyanto M, Gutomo T. Peran Keluarga Dalam Mewujudkan Lanjut Usia Sejahtera the Role of Family To Materialize Elderly Welfare. Media Inf Penelit Kesejaht Sosia. 2017;41(1):1-10.

19. Kelen APL, Hallis F, Putri RM. Tugas Keluarga Dalam Pemeliharaan Kesehatan Dengan Mekanisme Koping Lansia. Care. 2016;4(1):58-65. 